\title{
Gestational trophoblastic neoplasia after miscarriage with dilatation and curettage with normal histological findings
}

\author{
Ciążowa neoplazja trofoblastu w następstwie poronienia u pacjentki z prawidłowymi wynikami \\ badania histopatologicznego po zabiegu łyżeczkowania jamy macicy
}

\author{
'Department of Gynecologic Oncology, Izmir Tepecik Research and Training Hospital, Izmir, Turkey \\ ${ }^{2}$ Department of Medical Oncology, Izmir Tepecik Research and Training Hospital, Izmir, Turkey \\ ${ }^{3}$ Department of Gynecology and Obstetrics, Izmir Tepecik Research and Training Hospital, İmir, Turkey \\ Correspondence: Ibrahim Gülhan, Department of Gynecologic Oncology, İmir Tepecik Research and Training Hospital, Gaziler Street, No: 468, 35120 Izmir, Turkey, \\ tel.: 05067146590 , e-mail: drigulhan@yahoo.com
}

\begin{abstract}
Gestational trophoblastic neoplasia may develop after a molar, term, ectopic pregnancy, or an abortion. The diagnosis of gestational trophoblastic neoplasia can be made solely based on changes in human chorionic gonadotropin levels without pathologic confirmation. It is important to distinguish molar pregnancy from that disease, as treatment for these entities differs. However, gestational trophoblastic neoplasia developing after a term or ectopic pregnancy, or an abortion may be difficult to diagnose, because there is no tissue confirmation. In such cases, the time between a previous pregnancy event and the current event, and an inconsistency between very high levels of human chorionic gonadotropin and the size of lesions in the uterine cavity may be warning signs of gestational trophoblastic neoplasia. The role of curettage in the treatment of the disease is limited. We present a case of gestational trophoblastic neoplasia that developed after an abortion, serving as a reminder illustration that gestational trophoblastic neoplasia can develop not only after molar pregnancies, but also after other pregnancy events.
\end{abstract}

Keywords: molar pregnancy, gestational trophoblastic neoplasia, abortion, curettage

Streszczenie

Ciążowa neoplazja trofoblastu może rozwinąć się jako powikłanie zaśniadu groniastego, ciąży donoszonej, pozamacicznej, zakończonej zarówno poronieniem, jak i w wyniku zabiegu. Rozpoznanie możliwe jest w oparciu o sam poziom ludzkiej gonadotropiny kosmówkowej, bez konieczności potwierdzenia histopatologicznego. Istotne jest rozróżnienie tej jednostki chorobowej od zaśniadu groniastego, jako że sposoby leczenia obu chorób różnią się. Niemniej jednak ciążowa neoplazja trofoblastyczna rozwijająca się w następstwie ciąży donoszonej, pozamacicznej lub zakończonej poronieniem bądź zabiegiem przerwania ciąży może być trudna do rozpoznania z powodu braku potwierdzenia w postaci materiału tkankowego. W takich przypadkach wykładnikiem objawów chorobowych może być czas od ostatniej ciąży do obecnego stanu ciążowego w połączeniu z nieadekwatnie wysokim stężeniem ludzkiej gonadotropiny kosmówkowej oraz wielkością zmian obecnych w macicy. Zabieg łyżeczkowania jamy macicy odgrywa ograniczoną rolę w leczeniu ciążowej neoplazji trofoblastycznej. W niniejszej pracy przedstawiamy przypadek ciążowej neoplazji trofoblastu, która rozwinęła się po przebytym poronieniu, w celu przypomnienia, iż choroba ta może wystąpić jako powikłanie każdej ciąży, nie tylko zaśniadowej.

Słowa kluczowe: zaśniad groniasty, ciążowa neoplazja trofoblastu, przerwanie ciąży, poronienie, łyżeczkowanie jamy macicy 


\section{INTRODUCTION}

$\mathrm{T}$ he term "gestational trophoblastic neoplasia" (GTN) is used to describe a metastatic or non-metastatic persistent disease that develops after a molar, term, or ectopic pregnancy. Pathologic confirmation is not necessary for its diagnosis ${ }^{(1)}$. However, tissue confirmation is always helpful in making a definitive diagnosis. Within this context, the diagnosis of GTN developing after a molar pregnancy can be made easily based solely on changes in human chorionic gonadotropin (HCG) levels, without pathologic confirmation, because there is already pathology from the previous molar pregnancy $y^{(1)}$. However, in the case of GTN developing after a term or ectopic pregnancy, or an abortion, diagnosis can be difficult because there is no tissue confirmation, particularly in situations where anamnesis cannot be taken reliably. In such cases, the interval between the previous pregnancy event and the current event may be important. It can be easier to make a GTN diagnosis if this interval is too short to indicate a new pregnancy event, and the patient is sure that she used contraception properly. However, when the time after the previous pregnancy event is sufficiently long for a subsequent pregnancy to occur, and the patient did not use contraception, it is difficult to distinguish between molar pregnancy and GTN. It is important to distinguish between the two diseases, because the treatment of each is different. Another diagnostic criterion in this situation is an inconsistency between a very high level of HCG and the size of the lesion(s) in the uterine cavity. In a molar pregnancy, the cavity is full of trophoblastic lesions, and the appearance is typical on ultrasound, whereas in a GTN case, the cavity may be nearly empty.

This report, in which we present a GTN case that developed after an abortion, is aimed as a reminder for physicians that GTN may develop not only after molar pregnancies, but also after other pregnancy events. We also wanted to draw attention to the role of curettage in the treatment of GTN.

\section{CASE}

A 39-year-old (G2P1-C/S), 6-week pregnant woman was admitted to the hospital due to vaginal bleeding and underwent curettage based on a diagnosis of inevitable abortion. The pathology revealed a missed abortion. About 1 month after this intervention, she was admitted to the same hospital with vaginal bleeding, and was then referred to our hospital because of a very high level of HCG. We performed curettage to control the bleeding after observing a molar pregnancy-like ultrasound image. The HCG level was measured at $114,735 \mathrm{mIU} / \mathrm{mL}$ during the initial evaluation performed at our hospital. The pathology of the curettage material was reported as "trophoblastic proliferation - cannot rule out molar pregnancy." The HCG level dropped to $11,833 \mathrm{mIU} / \mathrm{mL}$ at 2 weeks after curettage (Tab. 1). After neglecting the regular follow-up visits for 1 month, the patient was admitted to the hospital again and hospitalized for evaluation, as her HCG level was measured at $128,935 \mathrm{mIU} / \mathrm{mL}$. Her HCG rose to $189,423 \mathrm{mIU} / \mathrm{mL}$ during the 4-day evaluation period in our hospital. The pelvic examination, chest $\mathrm{X}$-ray and abdominal ultrasound were all normal. Pelvic ultrasound revealed millimetric anechoic cystic lesions at the anterior corpus of the uterus, which has no clear border with the bladder. The uterine cavity was empty, and the endometrial thickness was $4 \mathrm{~mm}$. With these findings, the patient was diagnosed with nonmetastatic GTN developing after an abortion, and treatment was started following International Federation of Gynecology and Obstetrics (FIGO) scoring ${ }^{(1)}$. The FIGO GTN scoring was as follows: previous gestational history, abortion, 1 point, and pretreatment HCG level, 189,423 $\mathrm{mIU} / \mathrm{mL}$, 4 points, for a total of 5 points $^{(2)}$. Considering this case as low-risk non-metastatic GTN, we recommended singleagent chemotherapy. In our department, we apply a regimen of four sequential doses of methotrexate (MTX) and folinic acid for these patients ${ }^{(3)}$. According to this protocol, a $50 \mathrm{mg}$ MTX intramuscular injection is repeated every 48 hours, for a total of four doses, and $15 \mathrm{mg}$ folinic acid is given orally 30 hours after each injection of MTX every 15 days, until HCG is within the normal range. In our case, HCG was normal after four treatments; we administered two more treatments (six treatments in total), and then the patient entered follow-up. We also started oral contraceptives with the chemotherapy.

\section{DISCUSSION}

While $50 \%$ of GTN cases develop after a molar pregnancy, the remaining $50 \%$ develop after a term pregnancy, abortion, or ectopic pregnancy ${ }^{(1)}$. As mentioned previously, it is easier to diagnose GTN developing after a molar pregnancy then GTN that develops after other pregnancy events. Because an HCG increase or plateau can be easily determined, therapy can be started immediately, as the patient

\begin{tabular}{|c|c|}
\hline Date & HCG level (mlU/mL) \\
\hline 1. 15.10 .2016 & 114,735 - curettage \\
\hline 2. 26.10 .2016 & 11,833 \\
\hline 3. 21.11 .2016 & 128,935 \\
\hline 4. 24.11 .2016 & 189,423 - MTX started \\
\hline 5. 30.11 .2016 & 58,436 \\
\hline 6. 05.12 .2016 & $3,085-2^{\text {nd }}$ MTX \\
\hline 7. 16.12 .2016 & 106 \\
\hline 8. 22.12 .2016 & $42-3^{\text {rd }}$ MTX \\
\hline 9. 29.12 .2016 & 16 \\
\hline 10. 05.01 .2017 & $7.5-4^{\text {th }}$ MTX \\
\hline
\end{tabular}

Tab. 1. Changes in HCG levels by curettage and treatment 
is already in follow-up. However, the HCG level is equally important in GTN cases developing after other pregnancy events, and HCG changes after an ectopic pregnancy or an abortion should be monitored for the possibility of $\mathrm{GTN}^{(4)}$. A very high level of HCG, lack of evidence of pregnancy in the uterine cavity or pelvis, and the history of abortion 1 month earlier helped us to make the GTN diagnosis in this case. The empty uterine cavity in our patient, as well as an HCG level of 190,000, was an important factor in ruling out a molar pregnancy. We think that this high level of HCG may have been caused by trophoblastic cells, which invaded the myometrium similarly to invasive moles.

Any patient with bleeding after a past pregnancy event should be evaluated for GTN, because the most prevalent symptom of GTN, particularly when it develops after an abortion, is irregular vaginal bleeding ${ }^{(5)}$. In our case, hospital admission also occurred due to post-abortion vaginal bleeding.

Although the main treatment approach in non-metastatic low-risk disease is single-agent chemotherapy, curettage may be used in certain situations ${ }^{(6,7)}$. Thus, curettage was performed in our case at first admittance because of bleeding, but upon a continued increase in HCG during the follow-up period after curettage, we decided to start single-agent chemotherapy. Curettage is rarely used in the treatment of GTN because of the risk of bleeding and rupture or treatment failure. It is particularly recommended that HCG be below 1,500 or 5,000, to minimize complications if curettage is planned in the treatment of patients without bleeding ${ }^{(3,5,8)}$. Although we performed curettage to control the bleeding, we think that the very high level of HCG may have prevented this treatment from being curative. A very high level of HCG can be indicative of a large amount of trophoblastic cells in the uterine wall, which may stimulate further trophoblastic proliferation ${ }^{(9)}$. In conclusion, the possibility of GTN after abortion or other pregnancy events should be kept in mind, and a diagnostic workup specific to GTN should be conducted, particularly in patients with irregular vaginal bleeding. Classical GTN protocols should be used in treatment, and curettage should only be performed in the presence of certain indications and conditions.

\section{Conflict of interest}

The authors do not report any financial or personal connections with other persons or organizations which might negatively affect the content of this publication and/or claim authorship rights thereto.

\section{References}

1. Ngan HYS, Seckl MJ, Berkowitz RS et al.: Update on the diagnosis and management of gestational trophoblastic disease. Int J Gynaecol Obstet 2015; 131 Suppl 2: S123-S126.

2. Ngan HYS, Bender H, Benedet JL et al.; FIGO Committee on Gynecologic Oncology: Gestational trophoblastic neoplasia, FIGO 2000 staging and classification. Int J Gynaecol Obstet 2003; 83 Suppl 1: 175-177.

3. Seckl MJ, Sebire NJ, Fisher RA et al.; ESMO Guidelines Working Group: Gestational trophoblastic disease: ESMO Clinical Practice Guidelines for diagnosis, treatment and follow-up. Ann Oncol 2013; 24 Suppl 6: vi39-vi50.

4. Stenman UH, Alfthan H: Determination of human chorionic gonadotropin. Best Pract Res Clin Endocrinol Metab 2013; 27: 783-793.

5. Royal College of Obstetricians and Gynaecologists: The Management of Gestational Trophoblastic Disease. RCOG Green-top Guideline No. 38, February 2010

6. Garner EI, Feltmate CM, Goldstein DP et al.: The curative effect of a second curettage in persistent trophoblastic disease: a retrospective cohort survey. Gynecol Oncol 2005; 99: 3-5.

7. Osborne RJ, Filiaci VL, Schink JC et al.: Second curettage for low-risk nonmetastatic gestational trophoblastic neoplasia. Obstet Gynecol 2016; 128: 535-542.

8. Pezeshki M, Hancock BW, Silcocks P et al.: The role of repeat uterine evacuation in the management of persistent gestational trophoblastic disease. Gynecol Oncol 2004; 95: 423-429.

9. Cole LA: hCG, the wonder of today's science. Reprod Biol Endocrinol 2012; 10: 24. 